\title{
ISOLASI BAKTERI HETEROTROF DI SITU CIBUNTU, JAWA BARAT DAN KARAKTERISASI RESISTENSI ASAM DAN LOGAM
}

\section{ISOLATION OF HETEROTROPHIC BACTERIA FROM CIBUNTU POND, WEST JAVA AND CHARACTERIZATION OF METAL AND ACID RESISTANT}

\author{
Kesi Kurnia ${ }^{*}$, Nina Hermayani Sadi ${ }^{2}$, Syafitri Jumianto ${ }^{1}$ \\ ${ }^{1}$ Universitas Al Azhar Indonesia, Jl Sisingamangaraja Kebayoran Baru, 12110 Jakarta Selatan \\ ${ }^{2}$ Lembaga Ilmu Pengetahuan Indonesia, Jl Raya Jakarta-Bogor Km 46, Cibinong Bogor 16911
}

*Corresponding author: kesi.kurnia@gmail.com

Naskah Diterima: 24 April 2016; Direvisi: 1 Desember 2016; Disetujui: 1 Desember 2016

\begin{abstract}
Abstrak
Bakteri heterotrofik sangat berperan penting dalam sistem perairan karena kemampuan aktivitas metabolismenya. Bakteri tersebut berinteraksi dengan logam dan mineral dalam lingkungan alam dan sintetis, mengubah keadaan fisik dan kimianya sehingga mempengaruhi aktivitas, pertumbuhan dan kelangsungan hidup bakteri. Penelitian ini bertujuan untuk mengisolasi dan mengkarakterisasi bakteri resisten logam timbal $(\mathrm{Pb})$ dan asam di Situ Cibintu, Cibinong, Jawa Barat. Sampel air diambil dari 3 titik di Situ Cibuntu dan dianalisis distribusi bakteri heterotrofiknya. Isolat bakteri dikultur di media Triptone Glucose Yeast (TGY). Selanjutnya dilakukan resistensi terhadap logam timbal $(\mathrm{Pb})$ dan asam. Hasil penelitian menunjukkan bahwa jumlah bakteri heterotrof di Situ Cibuntu rata-rata $3,5 \times 10^{3} \mathrm{cfu} \mathrm{m} / \mathrm{L}$. Mayoritas $(73 \%)$ isolat bakteri resisten terhadap logam timbal sebanyak $47 \%$ dan resisten terhadap asam $(\mathrm{pH} 4)$. Bakteri yang resisten didominasi oleh Gram negatif. Penelitian ini memberikan pengetahuan mengenai kemampuan adaptasi bakteri heterotrof pada lingkungan logam dan asam.
\end{abstract}

Kata kunci: Bakteri heterotrof; Resisten asam; Resisten logam; Situ Cibuntu

\section{Abstract}

Heterotrophic bacteria play an important role in aquatic systems because of their ability of metabolic activities. They interact with metals and minerals in natural and synthetic environments, altering their physical and chemical state, that affect the microbial activity, by growth and survival. The purpose of study is to isolate and characterize the lead (Pb) and acid resistant of heterotrophic bacteria strains isolated from Cibuntu lake, Cibinong, West Java. Water samples were collected from three points around Cibuntulake and the distribution of heterotrophic bacteria were anlized. The bacterial isolates were screened on Triptone Glucose Yeast (TGY) agar plates. Lead $(\mathrm{Pb})$ metal and acidic tolerance were tested. In the present study, the population density of the heterotrophic bacteria were recorded of $3.5 \times 10^{3}$ cfu $\mathrm{m} / \mathrm{L}$. The majority $(73 \%)$ of bacteria isolates were resistant to lead and $47 \%$ to acid ( $\mathrm{pH} 4$ ). The most abundant type of bacteria resistant bacteria are Gram negative. This experiment provides a fundamental information about the adaptation capabilities of heterotrophic bacteria in metal and acid environment.

Keywords: Acid resistant; Heterotrophic bacteria; Metal resistant; Pond Cibuntu

Permalink/DOI: http//:dx.doi.org/10.15408/kauniyah.v9i2.3080 


\section{PENDAHULUAN}

Perairan situ merupakan salah satu tipe ekosistem perairan tawar tergenang dengan ukuran kecil. Di lingkungan perairan tersebut, keterlibatan mikroorganisme jelas tidak dapat diabaikan (Feliatra, 2001). Bakteri heterotrofik mampu memanfaatkan bahan organik maupun anorganik pada lingkungan tempat tumbuhnya sebagai sumber nutrisi. Pada siklus biogeokimia di perairan danau, bakteri heterotrofik memiliki peran sebagai perombak dan mampu remineralisasi bahan-bahan organik menjadi komponen anorganik sederhana yang dikembalikan ke dalam tanah dan atmosfer sebagai hara (Luo et al., 2010).

Situ Cibuntu yang terletak di kompleks LIPI Cibinong Kabupaten Bogor Jawa Barat, dengan luas area $15.026 \mathrm{~m}^{2}$ dan kedalaman rata-rata $0,85 \mathrm{~m}$ merupakan laboratorium alam untuk mempelajari karakter limnologis khusus untuk perairan situ. Situ tersebut banyak menerima masukan bahan organik dari daerah sekelilingnya yang berupa lahan pertanian. Peningkatan bahan organik pada perairan dapat meningkatkan populasi bakteri heterotrof di Situ Cibuntu (Badjoeri \& Zarkasyi, 2010).

Masuknya limbah domestik pada perairan dapat menyebabkan perubahan tingkat keasaman $(\mathrm{pH})$ dan kadar logam yang dapat berdampak pada organisme di dalam perairan tersebut. Kondisi yang sangat asam dapat menyebabkan kerusakan membran dan lepasnya komponen intraseluler bakteri sehingga dapat menyebabkan kematian pada bakteri. Logam berat seperti timbal $(\mathrm{Pb})$ merupakan bahan pencemar berbahaya karena sifatnya yang tidak dapat didegradasi (non degradable) oleh mikroorganisme hidup di lingkungan, sehingga apabila terakumulasi bahkan mengendap di dasar perairan maka dapat membentuk senyawa kompleks bersama bahan organik dan anorganik secara proses kimiawi (Badjoeri \& Zarkasyi, 2010). Oleh karena itu, penelitian ini bertujuan untuk mengisolasi dan memberikan informasi mengenai sifat resistensi asam $(\mathrm{pH} 4)$ dan resistensi logam timbal 100 ppm pada bakteri di Situ Cibuntu.

\section{MATERIAL DAN METODE}

Penelitian ini dilakukan di Laboratorium Mikrobiologi Limnologi Lembaga Ilmu Pengetahuan Indonesia (LIPI), Cibinong. Sampel air diambil dari Situ Cibuntu yang berada di kompleks LIPI Cibinong (Gambar 1). Sampel air diambil secara aseptik menggunakan botol steril dan disimpan dalam cooling box.

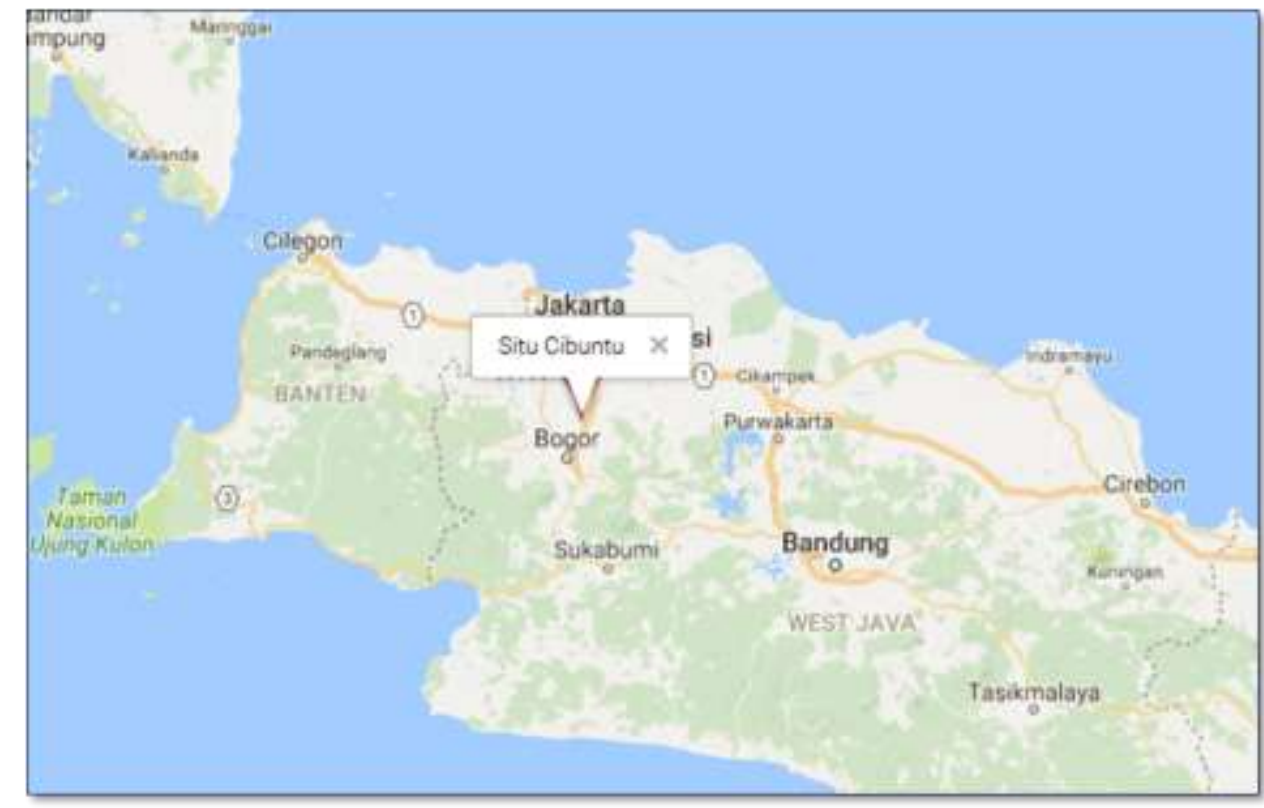

Gambar 1. Lokasi pengambilan sampel di Situ Cibuntu, Cibinong, Jawa Barat (Geographical Names, 2004) 


\section{Perhitungan Total Bakteri}

Sampel air dianalisis secara mikrobiologi dengan dikultur menggunakan metode pengenceran pada media nonselektif agar Triptone Glucose Yeast (TGY) secara duplo. Kelimpahan total bakteri heterotrofik dihitung menggunakan metode Colony Forming Units (CFU's)/mL. Isolat bakteri selanjutnya dilakukan karakterisasi meliputi uji Gram, resistensi asam, dan resistensi logam.

\section{Uji Gram}

Uji Gram dilakukan dengan mencampurkan satu lup isolat bakteri pada kaca objek yang telah ditetesi $\mathrm{KOH} 3 \%$ sebanyak $10 \mu \mathrm{L}$, kemudian diamati terbentuk tidaknya lendir. Jika terbentuk lendir maka bakteri tersebut dikelompokkan ke dalam Gram negatif namun jika tidak terbentuk lendir maka tergolong Gram positif.

\section{Uji Resistensi Asam}

Pada uji resistensi asam, isolat bakeri diinokulasikan pada media Nutrient Broth (NB) yang sebelumnya sudah ditambahkan $\mathrm{HCl}$ sehingga memiliki $\mathrm{pH}$ 4. Bakteri yang tahan asam akan tumbuh dan menyebabkan media menjadi keruh.

\section{Uji Resistensi logam}

Uji resistensi logam dilakukan dengan menginokulasikan bakteri pada media Nutrient Agar (NA). Selanjutnya kertas cakram steril yang mengandung $\mathrm{Pb} 100$ ppm diletakkan di atas koloni bakteri. Bakteri yang tahan logam akan menunjukkan pertumbuhan di sekeliling kertas cakram tersebut.

\section{HASIL}

Jumlah bakteri yang diisolasi di Situ Cibuntu yang berkisar $3,5 \times 10^{3} \mathrm{CFU} / \mathrm{mL}$ menunjukkan tingginya bahan organik yang masuk ke perairan tersebut. Sejumlah bakteri tersebut dapat dikelompokkan menjadi dua kelompok yaitu bakteri Gram positif dan Gram negatif. Hasil uji Gram diperoleh bahwa jumlah bakteri Gram negatif (60\%) lebih dominan dibandingkan Gram positif (40\%) yang terdapat di Situ Cibuntu (Gambar 2). Hasil uji resistensi terhadap logam $\mathrm{Pb}$ menunjukkan bahwa $73 \%$ populasi bakteri di Situ Cibuntu lebih resistensi terhadap logam $\mathrm{Pb}$ dibandingkan bakteri yang senstif (27\%) (Gambar 2).

Hasil uji ketahanan asam ( $\mathrm{pH} 4)$ berdasarkan kelompok bakteri Gram positif dan Gram negatif bahwa sensitifitas bakteri Gram positif lebih tinggi dibandingkan Gram negatif. Sebaliknya bakteri Gram negatif lebih resisten terhadap asam dibandingkan bakeri Gram positif (Gambar 3).

Hasil uji ketahanan terhadap logam $\mathrm{Pb}$ (100 ppm) antara kelompok bakteri Gram positif dan Gram negatif menunjukkan bahwa bakteri Gram negatif lebih resisten dibanding dengan bakteri Gram positif (Gambar 4).

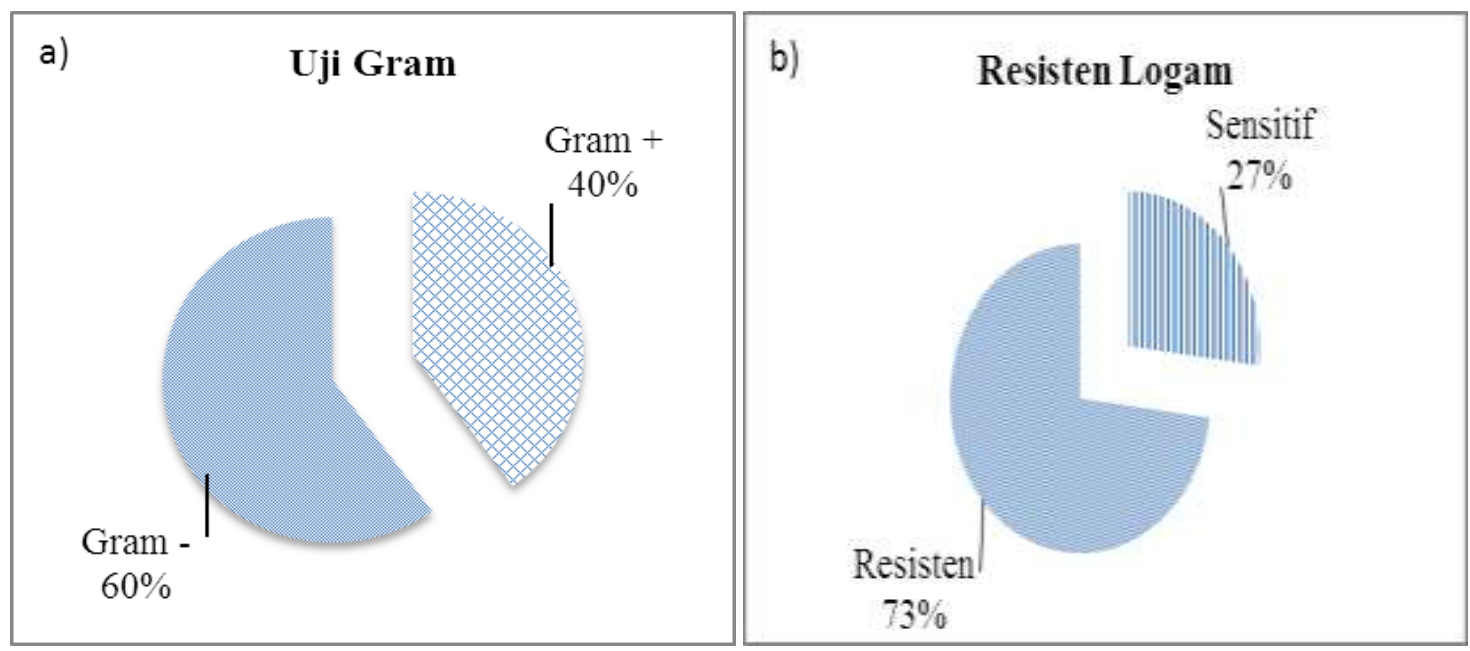

Gambar 2. Karakterisasi isolat bakteri Situ Cibuntu, Jawa Barat 


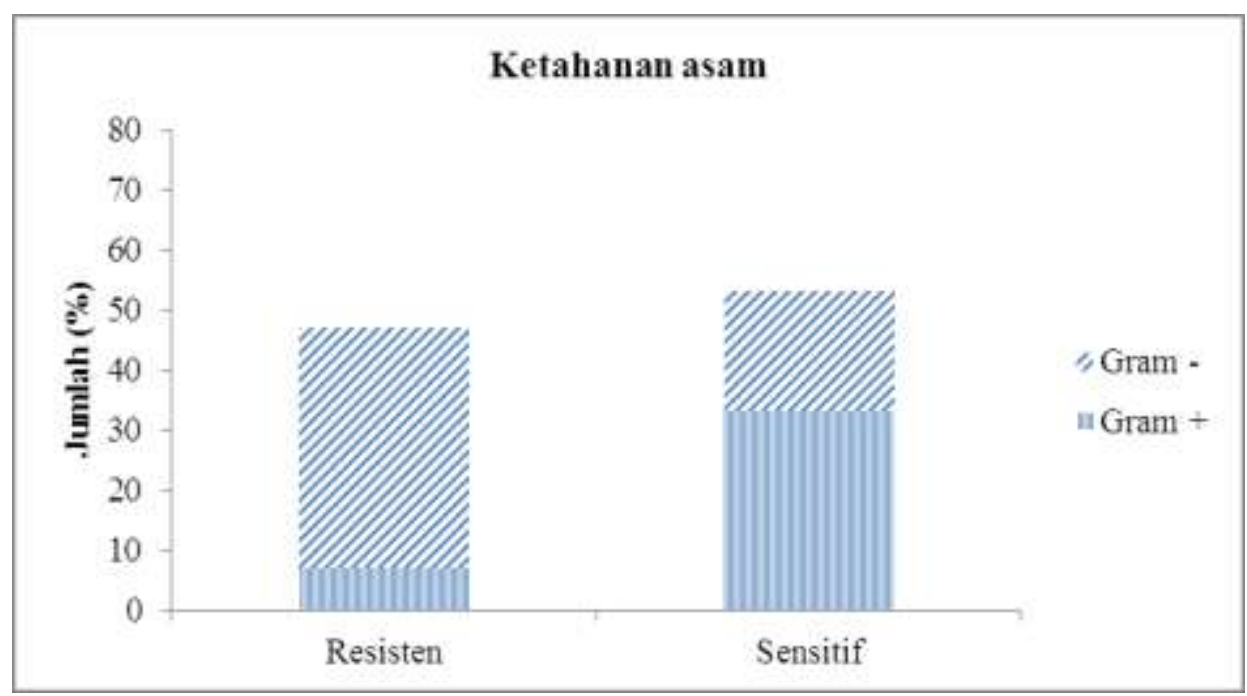

Gambar 3. Ketahanan asam terhadap bakteri Gram positif dan Gram negatif

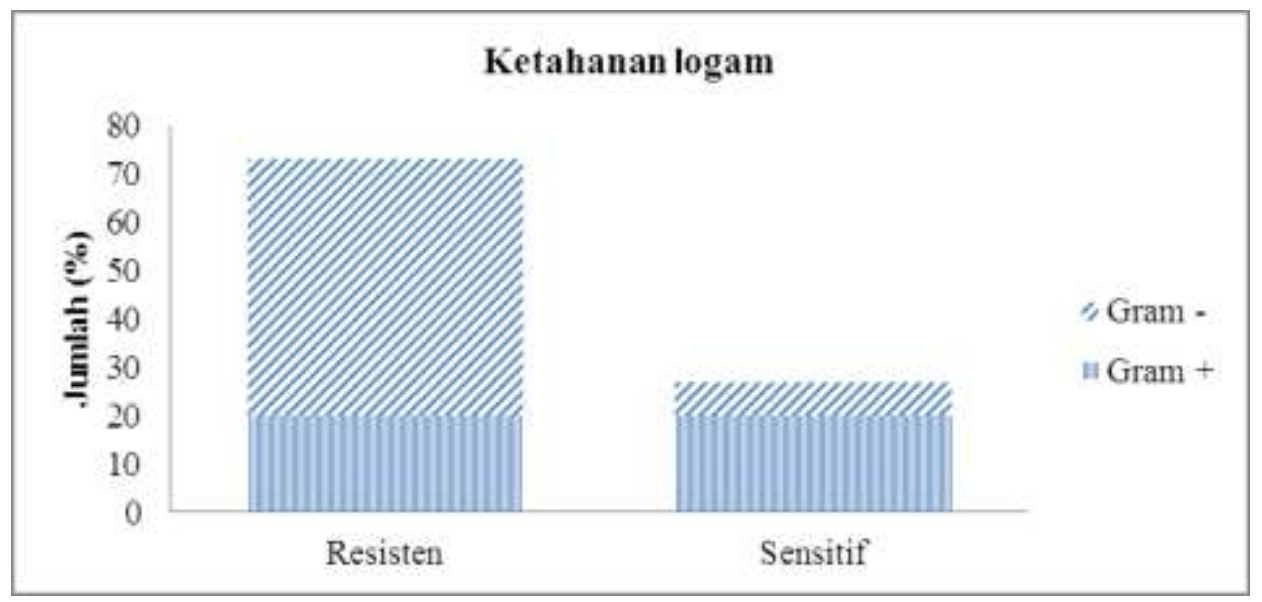

Gambar 4. Ketahanan terhadap logam Pb pada bakteri Gram positif dan Gram negatif

\section{PEMBAHASAN}

Bakteri heterotrof dapat memperoleh makanan yang berupa zat organik dari lingkungannya yang kemudian dirombak atau didekomposisi dan diremineralisasi menjadi unsur-unsur hara. Dalam ekosistem perairan, organisme perombak seperti bakteri heterotrof memanfaatkan sisa organisme yang telah mati untuk diurai menjadi unsur-unsur yang dikembalikan ke dalam tanah dan atmosfer sebagai hara yang dapat digunakan kembali oleh tanaman (Aminulloh, 2011).

Bakteri yang diisolasi dari Situ Cibuntu menunjukkan sebanyak $40 \%$ Gram positif dan $60 \%$ Gram negatif (Gambar 2a). Penggunaan metode Gram menggunakan $\mathrm{KOH}$ disebabkan lebih mudah dan praktis dibanding prosedur pewarnaan Gram. Bakteri Gram positif memiliki dinding sel yang tebal dan lemak yang tipis sedangkan Gram negatif memiliki lemak tebal dan berdinding sel tipis yang berada di ruang periplasma. $\mathrm{KOH}$ akan menyerang lemak (bilayer lipid) dan membuat sel bakteri Gram negatif pecah sedangkan Gram positif tidak terpengaruh (Chandra \& Mani, 2011).

Bakteri yang resisten terhadap asam lebih sedikit dibanding bakteri yang sensitif (Gambar 3). Bakteri yang tahan terhadap asam memiliki ketahanan yang lebih besar terhadap kerusakan membran akibat penurunan $\mathrm{pH}$ dibandingkan bakteri yang tidak tahan terhadap asam. Menurut Susanti et al., (2007) komposisi asam lemak dan protein penyusun membran yang beragam di antara spesies bakteri diduga mempengaruhi keragaman ketahanan bakteri terhadap $\mathrm{pH}$ rendah. Perbedaan tersebut di- 
sebabkan karakter fisiologis dari masingmasing bakteri yang berbeda-beda.

Sebanyak $73 \%$ bakteri lebih resisten terhadap logam (Gambar 4). Bakteri yang tahan terhadap toksisitas logam berat mengalami perubahan sistem transpor di membran selnya sehingga terjadi penolakan atau pengurangan logam yang masuk ke dalam sitoplasma. Pada bakteri yang tahan logam, logam yang tidak dapat melewati membran sel akan terakumulasi dan diendapkan atau diserap di permukaan sel (Arrizal et al., 2013). Pengikatan logam berat oleh bakteri dapat dipisahkan menjadi fase pengikatan dan transport aktif (Arrizal et al., 2013).

Banyak isolat bakteri Gram negatif yang resisten terhadap asam maupun logam. Menurut Susanti et al., (2007) toleransi relatif dari mikroorganisme terhadap lingkungan asam tergantung dari galur bakteri. Komposisi asam lemak dan protein penyusun membran yang beragam diantara spesies bakteri juga mempengaruhi keragaman ketahanan bakteri pada $\mathrm{pH}$ rendah (Susanti et al., 2007). Selain itu, Ahmad et al., (2005) juga menyatakan bahwa bakteri Gram negatif umumnya lebih toleran terhadap pengaruh logam berat dibandingkan bakteri Gram positif karena struktur dinding selnya yang kompleks sehingga dapat mengikat dan mengimobilisasi sebagian besar ion logam termasuk $\mathrm{Pb}^{2+}$. Umumnya daya tahan bakteri terhadap berbagai jenis logam berat disebabkan adanya suatu faktor penentu yang memberikan resistensi terhadap satu atau sejumlah kecil logam berat. Resistensi tersebut berhubungan dengan gen di kromosom, plasmid atau transposon yang mengatur mekanisme seperti transport aktif yang melibatkan ATP untuk $\mathrm{Pb}$ (Zulaika et al., 2012). Mekanisme resistensi pada bakteri meliputi pengaliran logam keluar sel bakteri, modifikasi spesies logam, pengurangan logam, atau kombinasi dari mekanisme tersebut (Bontidean et al., 2003).

\section{KESIMPULAN}

Penelitian ini menunjukkan bahwa bakteri heterotrof dari Situ Cibuntu sebagian besar resisten terhadap logam tapi masih sensitif terhadap asam. Bakteri yang resisten didominasi oleh Gram negatif.

\section{REFERENSI}

Ahmad, I., Hayat, S., Ahmad, A., Inam, A., \& Samiullah. (2005). Effect of heavy metal on survival of certain groups of indigenous soil microbial population. Journal Applied Science Environment, 115-121.

Aminulloh, F. (2011). Analisis bahan organik dan nitrogen total pada sistem budidaya ikan pada skala laboratorium. Bogor: Program Keahlian Analisis Kimia IPB.

Arrizal, S., Rachmadiarti, F., \& Yuliani. (2013). Identifikasi rhizobakteri pada semanggi (Marsilea crenata Presl.) yang terpapar logam berat timbal $(\mathrm{Pb})$. Lentera Biologi, 2, 165-169.

Badjoeri, M., \& Zarkasyi, H. (2010). Isolasi dan seleksi bakteri bioremoval logam berat merkuri. Prosiding Seminar Nasional Limnologi V, 543-556.

Bontidean, et al. (2003). Novel synthetic phytochelatin-based capacitive biosensor for heavy metal ion detection. Biosensors Bioelectronics, 18, 547-553.

Chandra, T. J., \& Mani, S. (2011). A study of 2 rapid tests to differentiate Gram positive and Gram negative aerobic bacteria. Journal Medicine Allied Science, 1(2), 84-85.

Feliatra. (2001). Isolasi dan identifikasi bakteri heterotrof yang terdapat pada daun mangrove (Avicenna sp. dan Sonneratia sp.) dari kawasan stasiun kelautan Dumai. Journal Natur Indonesia III, 104-112.

Geographical Names. (2004). Situ Cibuntu: Indonesia. (2016 Agustus 8). Retrived from http://www.geographic.org/geogra phic_names/name.php?uni=9237167\&fid $=2546 \& \mathrm{c}=$ indonesia

Luo, Y. W., Friedrichs, M. A. M., Doney, S. C., Church, M. J., \& Ducklow, H. W. (2010). Oceanic heterotrophic bacterial nutrition by semilabile DOM as revealed by data assimilative modeling. Aquatic Microbiology Ecology, 273-287. 
Susanti, I., Kusumaningtyas, R., \& Illaningtyas, F. (2007). Uji sifat probiotik bakteri asam laktat sebagai kandidat bahan pangan nasional. Jurnal Teknologi Industri Pangan XVIII, 89-95.

Zulaika, E., Luqman, A., Arindah, T., \& Sholikah, U. (2012). Bakteri resisten logam berat yang berpotensi sebagai bioasorben dan bioakumulator. $\mathrm{Di}$ dalam: Waste management for sustainable urban development: Surabaya 21 Feb 2012. Surabaya: Teknik Lingkungan Institut Teknologi Surabaya. 1-5. 